\title{
Slowed Biogeochemical Cycling in Sub-arctic Birch Forest Linked to Reduced Mycorrhizal Growth and Community Change after a Defoliation Event
}

\author{
Thomas C. Parker, ${ }^{1,2,5 *}$ Jesse Sadowsky, ${ }^{3}$ Haley Dunleavy, ${ }^{3}$ \\ Jens-Arne Subke, ${ }^{1}$ Serita D. Frey, ${ }^{3}$ and Philip A. Wookey ${ }^{4}$
}

\begin{abstract}
${ }^{1}$ Biological and Environmental Sciences, School of Natural Sciences, University of Stirling, Stirling FK9 4LA, UK; ${ }^{2}$ Department of Animal and Plant Sciences, University of Sheffield, Alfred Denny Building, Sheffield S10 2TN, UK; ${ }^{3}$ Department of Natural Resources and the Environment, University of New Hampshire, Durham, New Hampshire, USA; ${ }^{4}$ Environmental Sciences, School of Life Sciences, Heriot-Watt University, Edinburgh EH14 4AS, UK; ${ }^{5}$ Present address: The Ecosystems Center, Marine Biological Laboratory, Woods Hole, Massachusetts 02543, USA
\end{abstract}

\begin{abstract}
Sub-arctic birch forests (Betula pubescens Ehrh. ssp. czerepanovii) periodically suffer large-scale defoliation events caused by the caterpillars of the geometrid moths Epirrita autumnata and Operophtera brumata. Despite their obvious influence on ecosystem primary productivity, little is known about how the associated reduction in belowground $\mathrm{C}$ allocation affects soil processes. We quantified the soil response following a natural defoliation event in sub-arctic Sweden by measuring soil respiration, nitrogen availability and ecto-
\end{abstract}

Received 12 January 2016; accepted 23 June 2016; published online 25 August 2016

Electronic supplementary material: The online version of this article (doi:10.1007/s10021-016-0026-7) contains supplementary material, which is available to authorized users.

Author contributions TCP, HD, JA-S and PAW collected data, TCP, HD and JS conducted lab analyses, TCP and JS conducted statistical analyses, TCP, PAW, J-AS, SF and HD designed the study, TCP, PAW JS, $\mathrm{J}$-AS and SF wrote the paper.

*Corresponding author; e-mail: tomparker999@gmail.com mycorrhizal fungi (EMF) hyphal production and root tip community composition. There was a reduction in soil respiration and an accumulation of soil inorganic $\mathrm{N}$ in defoliated plots, symptomatic of a slowdown of soil processes. This coincided with a reduction of EMF hyphal production and a shift in the EMF community to lower autotrophic Cdemanding lineages (for example, /russula-lactarius). We show that microbial and nutrient cycling processes shift to a slower, less C-demanding state in response to canopy defoliation. We speculate that, amongst other factors, a reduction in the potential of EMF biomass to immobilise excess mineral nitrogen resulted in its build-up in the soil. These defoliation events are becoming more geographically widespread with climate warming, and could result in a fundamental shift in sub-arctic ecosystem processes and properties. EMF fungi may be important in mediating the response of soil cycles to defoliation and their role merits further investigation.

Key words: defoliation; nitrogen; carbon; birch forest; sub-arctic; ectomycorrhizal fungi; community change. 


\section{INTRODUCTION}

Mountain birch trees (B. pubescens Ehrh. ssp. czerepanovii (Orlova) Hämet Ahti) comprise the dominant treeline forests in most of the northern Fennoscandia (Tømmervik and others 2009; Hofgaard and others 2013). This forest is responsive to climate change, amongst other important drivers such as changes in reindeer management (Tømmervik and others 2009; Van Bogaert and others 2011). The birch treeline has been observed to have advanced both in latitude in the last century (Hofgaard and others 2013) and in elevation in the last 34 years (Rundqvist and others 2011).

Insect outbreaks are important controls over productivity in temperate, boreal (Hicke and others 2012) and sub-arctic ecosystems (Bjerke and others 2014). Cyclical outbreaks of the defoliating Autumnal Moth (Epirrita autumnata) and the Winter Moth (Operophtera brumata) are common and widespread across the mountain birch forests of Northern Scandinavia (Jepsen and others 2008). These outbreaks occur in waves across the Scandes mountains, with an approximate 10-year frequency (Tenow and others 2007), causing considerable damage to the canopy of B. pubescens forests (Jepsen and others 2013) and contributing towards large decreases in forest productivity (Bjerke and others 2014). It is not clear whether the frequency of these outbreaks is increasing with climate change, but the area of forest affected has increased by about $5^{\circ}$ East in longitude, into the colder continent, and about $2^{\circ}$ North in latitude over the last century (Jepsen and others 2008). This is thought to be due to a warming of winter climate, allowing over-winter survival of eggs in areas that were previously too cold (Jepsen and others 2008). With the distribution and severity of defoliator insect outbreaks expected to increase further with climate change (Bale and others 2002; Jepsen and others $2008,2011)$, it is important to understand how the mountain birch forest ecosystem responds to such disturbance. Furthermore, the potential links between forest dynamics and both net carbon fluxes and surface energy budget underscore the need to investigate the role of herbivores as modulators of climate change impacts in these ecosystems (Moore and others 2013).

Sub-arctic forests are known to influence soil carbon (C) fluxes and metabolism by allocating recently assimilated $\mathrm{C}$ belowground, stimulating the decomposition of soil organic $\mathrm{C}$ and the release of nutrients (Hartley and others 2012). Belowground transfer of labile $\mathrm{C}$ from trees to the rhizosphere drives microbial activity, soil respiration
(Högberg and others 2001) and $\mathrm{N}$ immobilisation (Kaiser and others 2011; Näsholm and others 2013a). Because defoliation reduces the ability of sub-arctic birch forests to fix C (Heliasz and others 2011), it is expected that defoliation events strongly reduce $\mathrm{C}$ inputs to the rhizosphere and slow biogeochemical cycles.

In addition to altering $\mathrm{C}$ allocation patterns, defoliation events in sub-arctic ecosystems accelerate nitrogen $(\mathrm{N})$ inputs into the soil via direct frass addition, thereby potentially altering $\mathrm{N}$ cycling (Kaukonen and others 2013). Nitrogen immobilisation in the soil is known to be driven by autotrophic C inputs (Kaiser and others 2011) and belowground $\mathrm{C}$ allocation is positively correlated with forest productivity (Litton and others 2007). In productive temperate ecosystems, the $\mathrm{N}$ cycle responds quickly to $\mathrm{N}$ additions from caterpillar frass through redistribution of $\mathrm{N}$ into microbial communities (Lovett and Ruesink 1995) or re-assimilation by the affected trees (Russell and others 2004; Frost and Hunter 2007). In a less productive ecosystem, such as the sub-arctic, reduced C supply to the rhizosphere alongside frass addition may result in an accumulation of 'available' $\mathrm{N}$ in the soil, as has previously been observed (Kaukonen and others 2013), and akin to an N-saturated ecosystem (Aber 1992).

Ectomycorrhizal fungi (EMF) are a major recipient of autotrophic $\mathrm{C}$ in forest ecosystems, with up to $20 \%$ of plant C allocated belowground transferred to the EMF community (Högberg and others 2001; Hobbie 2006). This C supply allows EMF species to maintain dominance in the organic horizon of boreal forest soils over free-living fungi (Lindahl and others 2007), but this dominance can be disrupted by cutting the autotrophic $C$ supply (Lindahl and others 2010). Therefore, any reduction in $\mathrm{C}$ inputs belowground may translate directly to a reduction in $\mathrm{C}$ supply to the mycorrhizosphere (Gehring and others 1997; Högberg and others 2001). EMF fungi have a large capacity to immobilise soil $\mathrm{N}$ in their biomass (Näsholm and others 2013a), and a reduction in EMF growth due to defoliation could significantly reduce their capacity to immobilise the free $\mathrm{N}$ that becomes available in such events (Kaukonen and others 2013).

When trees are defoliated, it has been speculated that EMF fungi with lower $\mathrm{C}$ demand from their autotrophic host hold a competitive advantage over species that require a larger $\mathrm{C}$ investment (Saikkonen and others 1999; Markkola and others 2004). Widespread defoliation should therefore drive a change in EMF community composition, selecting for less $\mathrm{C}$-demanding EMF taxa. A shift to 
exploration types (ET (Agerer 2001)), which produce less hyphal biomass, could have significant feedbacks for $\mathrm{C}$ and $\mathrm{N}$ cycling in the soil.

Carbon allocation to EMF can stimulate $\mathrm{N}$ immobilisation in low $\mathrm{N}$ environments by increasing uptake and incorporation into hyphal biomass (Näsholm and others 2013a). It has been shown that efficient uptake of $\mathrm{N}$ by EMFs further intensifies $\mathrm{N}$ limitation in the soil, thereby maintaining their host's reliance on them and competitively excluding non-EMF plants (Näsholm and others 2013a). This cycle could be broken by disturbance such as defoliation, where autotrophic C supply to EMF is reduced (Kuikka and others 2003) and mineral $\mathrm{N}$ becomes more readily available (Kaukonen and others 2013). High mineral N concentrations in the soil after defoliation events may be due in part to reduced immobilisation by EMF as a result of reduced C supply.

A mountain birch forest (B. pubescens ssp. czerepanovii) in sub-arctic Sweden was defoliated by a joint outbreak of the winter and autumnal moths (O. brumata and E. autumnata) in early summer of 2013 after an outbreak the previous year. This gave us the opportunity to measure the belowground response of this ecosystem to the associated reduction in autotrophic $C$ supply. In particular, we address the following research aims: 1 . to measure belowground $\mathrm{C}$ and $\mathrm{N}$ cycling in response to defoliation of the Betula canopy; 2. to compare hyphal growth and root tip community composition of ectomycorrhizal fungi in defoliated and non-defoliated plots; and 3. to understand better how changes (if any) in soil $\mathrm{C}$ and $\mathrm{N}$ cycling link to ectomycorrhizal community composition and growth in a sub-arctic forest ecosystem.

\section{Materials ANd Methods}

\section{Study Site}

Study sites were established in the treeline birch forest near Abisko, Sweden $\left(\sim 68^{\circ} 18^{\prime} \mathrm{N}, 18^{\circ} 49^{\prime} \mathrm{E}\right)$. The forest comprises mountain birch (B. pubescens Ehrh. ssp. czerepanovii (Orlova) Hämet Ahti) with a dominantly ericaceous understorey of Empetrum hermaphroditum, Vaccinium myrtillus, Vaccinium vitisidaea, Vaccinium uliginosum and some shrubs including Betula nana, Salix spp. and Juniperus communis. The soil is a thin spodosol developed over glacial till and bedrock typically of hard shale, with a thin $(<5 \mathrm{~cm}) \mathrm{O}$ horizon. Soil pH of the organic horizon is $4.5 \pm 0.1 \quad$ (mean \pm standard error) (Parker and others 2015). Further details on soil properties can be found in Sjögersten and Wookey
(2002) and Hartley and others (2010). The forest defoliation event by O. brumata and E. autumnata began in May 2013 as budburst occurred across the forest, although the exact timing was highly dependent on local microclimates. The trees were at their maximum extent of defoliation and caterpillars were no longer present in the trees by 19th June 2013 (Figure 1). There was also widespread defoliation due to an outbreak by the same species the previous summer, which is unusual, but this earlier outbreak was not documented in detail in this study area.

\section{Study Design}

Based on the visual extent of defoliation, replicate trees across a forest stand were selected as either non-defoliated (at least 95\% of leaves remaining) or defoliated (max. $5 \%$ of leaves remaining), with $n=5$ per group (Figure 1). The trees were selected in geographical pairs over forested areas of approximately $19,000 \mathrm{~m}^{2}$, and paired individuals were, on average, $18 \mathrm{~m}$ apart and $58 \mathrm{~m}$ from the closest other pair. In addition to the defoliated and non-defoliated plots in one B.pubescens forest stand, other forest stands were sampled to assess defoliation impacts at the landscape scale (LS). LS plots (24 in total, consisting of all trees within a $5 \mathrm{~m}$ radius of a central point) were distributed across multiple stands of mountain birch which showed contrasting degrees of defoliation (11.5$96.1 \%$ canopy defoliated in July 2013) over a $2 \mathrm{~km}^{2}$ area. To quantify defoliation in each plot, every B. pubescens individual was estimated for percentage of leaves remaining, which was then converted to percentage defoliated (assuming a full canopy prior to defoliation). Defoliation values are means of independent estimates by two observers. Respiration and ion exchange measurements were taken at the defoliated and non-defoliated paired plots; ion exchange, EMF ingrowth and EMF root tips assessments were taken at the LS plots.

\section{Respiration}

At defoliated and non-defoliated plots, two PVC collars ( $15 \mathrm{~cm}$ diameter $\times 7 \mathrm{~cm}$ high) were fixed to the soil surface at 50 and $150 \mathrm{~cm}$ from the base of each tree (Figure 1). To avoid disturbance to the rhizosphere, collars were not pushed into the soil, but were sealed to the soil using non-setting putty (Plumber's Mait ${ }^{\circledR}$, Bostik Ltd, Stafford, UK). Collar locations were selected to have low plant cover within the collar (live understorey $<20 \%$, for both defoliated and non-defoliated plots) and therefore 


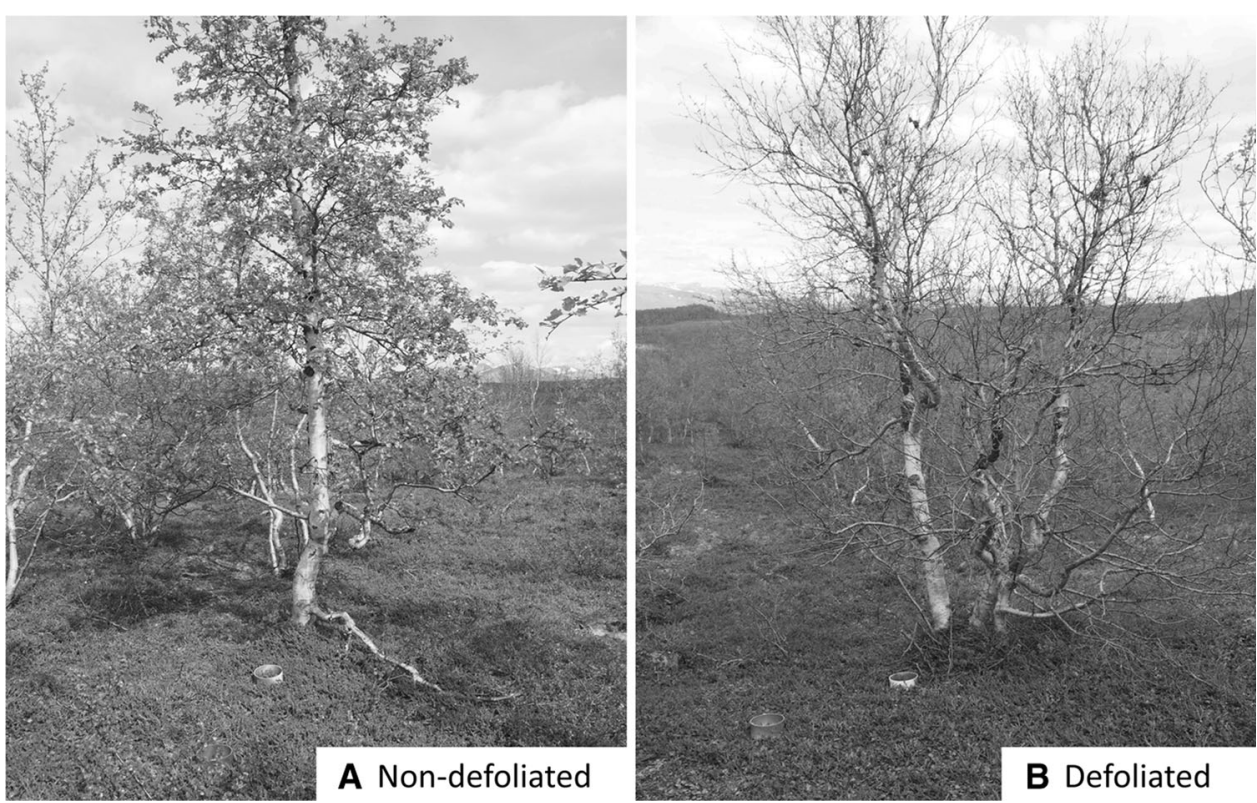

Figure 1. Two Betula pubescens study trees assigned to A "nondefoliated" and B "defoliated" categories based on the extent of defoliation by Operophtera brumata and/or Epirrita autumnata on 19th June 2013. Collars to measure soil respiration can be seen at 50 and $150 \mathrm{~cm}$ from the base of each tree.

capture soil respiration best while causing minimal extra disturbance to the study system over the short period of time available for measurement. A good seal with the ground was confirmed as all respiration measurements showed a linear increase in $\mathrm{CO}_{2}$ concentration over time (over $90 \mathrm{~s}$ ). Live understorey plant cover was low (c 20\%) and did not differ between defoliated and non-defoliated collars in the plots.

Soil respiration measurements (which included both microbial and plant components, including very low shoot components) were made with a portable EGM-4 infrared gas analyser with a darkened CPY-2 chamber (PP Systems International, Amesbury, MA, USA). $\mathrm{CO}_{2}$ flux was measured five times at each collar through June and July 2013, after the defoliation event, and then twice in September 2013. Follow-up respiration measurements were made in June and July 2014 (one measurement each month). In 2014, 'defoliated' trees did not re-grow their canopy, instead investing in new shoots at their base. Respiration rates were calculated as the product of a linear function of $\left[\mathrm{CO}_{2}\right]$ increase over a period of $90 \mathrm{~s}$ within the closed system. Tests with longer measurement periods showed no improvement of fit. All collars were measured within a two-hour period between 09:00 and 16:00 h local time.

\section{Soil Inorganic Nitrogen Availability}

Anion and cation exchange membranes $(2.5 \times 5 \mathrm{~cm}$; Resintech, West Berlin, NJ, USA) were deployed in pairs approximately $5 \mathrm{~cm}$ apart to measure soil inorganic $\mathrm{N}$ availability in summer (10th-24th July 2013) and autumn (6th-20th September 2013). Membranes were regenerated in $0.5 \mathrm{M} \mathrm{HCl}$ for one hour before being neutralised in $0.5 \mathrm{M} \mathrm{NaCO}_{3}$ for five hours, replacing the $\mathrm{NaCO}_{3}$ every hour. The membranes were inserted vertically into the soil surface $(0-5 \mathrm{~cm})$ at the centre of all $L S$ plots. Care was taken to select soils with no moss species (for example, Pleurozium schreberi) associated with $\mathrm{N}$-fixing cyanobacteria (DeLuca and others 2002) to avoid measuring leached $\mathrm{N}$ from this potential source. A knife was used to create a vertical incision in the soil into which the membrane was carefully inserted. The soil was then pushed together to ensure good contact and membranes were left in situ for 14 days. Membranes were deployed in the same manner at the paired defoliated and non-defoliated trees, in between the soil respiration collars at $0.75 \mathrm{~m}$ from the base of the tree. After collection, adhering soil particles were gently brushed away, after which the membranes were rinsed with deionised water. Membranes were stored at $3^{\circ} \mathrm{C}$ for 18 days before extraction ( $100 \mathrm{rpm}$ for $60 \mathrm{~min}$ in $35 \mathrm{ml} 2 \mathrm{M} \mathrm{KCl}$ (Qian and Schoenau 2002)). Extractable $\mathrm{NH}_{4}{ }^{+}$and $\mathrm{NO}_{3}{ }^{-}$was quantified using flow injection analysis (FIAflow2, Burkard Scientific, Uxbridge, UK). Control strips ( $n=10$ per season) were taken into the field on the day of strip insertion but not placed in the field. They were taken back to the lab and stored at $3{ }^{\circ} \mathrm{C}$ until field samples were analysed, at which point they were processed in the same way. The mean amount of $\mathrm{NH}_{4}{ }^{+}$or $\mathrm{NO}_{3}{ }^{-}$adsorbed to 
control strips in each season was subtracted from field samples as an analytical blank.

\section{Ectomycorrhizal Hyphal Production}

Nylon mesh bags $(5 \times 4 \mathrm{~cm} ; 37 \mu \mathrm{m}$ mesh size $)$, which allowed ingrowth of hyphae, anticipated to be primarily of EMF fungi (analysis of community DNA shows c $80 \%$ EMF (Wallander and others 2013)) but not roots (Wallander and others 2001, 2013), were filled with $25 \mathrm{~g}$ of sand from the shore of Lake Torneträsk $\left(68^{\circ} 21 \mathrm{~N}, 18^{\circ} 49 \mathrm{E}\right)$. No plants were present aboveground within $1 \mathrm{~m}$ of the sand collection point. Sand was sieved to between 0.125 and $1 \mathrm{~mm}$, rinsed under a flow of water for $1 \mathrm{~min}$ then microwaved $(800 \mathrm{~W})$ for $12 \mathrm{~min}$, reaching a temperature of $98^{\circ} \mathrm{C}$. This process was repeated and the sand was rinsed a final time before drying for $48 \mathrm{~h}$ at $80^{\circ} \mathrm{C}$. The sand-filled bags were inserted at the LS plots within $0.5 \mathrm{~m}$ of the ion exchange membranes at the centre of the plots. Bags were inserted at the interface between organic and mineral horizons where mycorrhizal activity is at its highest (Lindahl and others 2007); in this case, each bag was placed between 2 and $7 \mathrm{~cm}$ depth. The bags were left in the field for 92 days between 16th June and 16th September 2013. This was deemed to be an appropriate time period as C allocation belowground continues into September in this ecosystem (Sloan and others 2015; BlumeWerry and others 2016). At collection, the sand was removed from the bags and freeze dried using a Modulyo ${ }^{\circledR}$ freeze drier (Thermo Fisher Scientific, Waltham, MA, USA) for $72 \mathrm{~h}$ within $6 \mathrm{~h}$ of recovery.

Sand ( $1 \mathrm{~g}$ ) from each bag was sonicated for $10 \mathrm{~min}$ in $30 \mathrm{ml}$ deionised water to disassociate the fungal hyphae from the sand particles. A $4 \mathrm{ml}$ aliquot of the water-hyphae suspension was filtered onto a nitrate cellulose filter paper $(0.45 \mu \mathrm{m}$ pore size) and fungal material was stained with trypan blue (following Quirk and others (2012)). Hyphal length was estimated under $\times 200$ magnification (Primo Star, Zeiss, Oberkochen, Germany) using the line intersect method (Brundrett and others 1994). This was repeated on duplicate samples for each mesh bag, a mean of which was taken as the final measurement.

\section{Ectomycorrhizal (EMF) Community Composition}

Root tips of non-defoliated and defoliated trees were collected and analysed to identify the EMF taxa colonising the roots. Samples were taken on 7th July 2013. Five pairs of defoliated and nondefoliated trees were selected to sample EMF root tips. Paired trees located within 5-10 m of each other were designated 'defoliated' or 'non-defoliated' based upon the percentage of leaves remaining, where about 0 to $15 \%$ were designated as 'defoliated' and about 85 to $100 \%$ were designated as 'non-defoliated'. Three of these paired plots were selected from the $L S$ plots and two from two additional mountain birch stands. At each tree, organic horizon soil was collected as $5.7 \mathrm{~cm}$ diameter cores to a depth of $4 \mathrm{~cm}$. Roots within each core were rinsed of adhering soil particles under a stream of tap water on a $1 \mathrm{~mm}$-mesh sieve. From each sample, 48 individual EMF-infected root tips were excised from larger root fragments under a stereomicroscope and stored in tap water at $4^{\circ} \mathrm{C}$ for up to 14 days prior to DNA extraction. EMF root tips were assumed to be of $B$. pubescens because the understorey is primarily ericaceous (ericoid mycorrhizal), with other EMF species present at these plots (B. nana) typically having very low cover $(8 \pm 2 \%$ (Parker and others 2015)).

To characterise EMF communities, fungal DNA of a random subset of 16 EMF root tips from a pool of 48 per plot was sequenced. Single root tip DNA was extracted with the Extract-N-Amp kit (Sigma, USA), according to Avis and others (2003). Fungal DNA was amplified using polymerase chain reaction (PCR) with the ITS1F-ITS4 primer set (White and others 1990; Gardes and Bruns 1993) at 0.35$\mu \mathrm{M}$ concentration in GoTaq G2 Master Mix (Promega, USA). The PCR consisted of a 3-min hot start at $95^{\circ} \mathrm{C}, 35$ cycles of $30 \mathrm{~s}$ at $95^{\circ} \mathrm{C}, 45 \mathrm{~s}$ at $60^{\circ} \mathrm{C}$ and $90 \mathrm{~s}$ at $72^{\circ} \mathrm{C}$, and a final cycle of $5 \mathrm{~min}$ at $72^{\circ} \mathrm{C}$. Negative controls (diethylpyrocarbonate-treated water) were included in each PCR run. PCR products were run in $0.05 \%$ ethidium bromide $1.5 \%$ agarose $(\mathrm{w} / \mathrm{v})$ gels and photographed under UV light to confirm single PCR amplicons. After primers and unincorporated nucleotides were removed using ExoSAP (Affymetrix, Cleveland, OH, USA), as described by Kennedy and Hill (2010), amplicons were sequenced with the ITS4 primer on a 3730XL Applied Biosystems sequencer by Macrogen Corp. (Rockville, MD, USA). Sequence chromatograms were edited in FinchTV 1.4.0 (Geospiza, Seattle, WA, USA) or 4peaks 1.7 (http:// nucleobytes.com/index.php/4peaks) to eliminate spurious base calls on the flanking ends of sequences.

Fungal sequences were assigned to one of approximately 80 described EMF lineages (Tedersoo and Smith 2013) or to the genus level for nonEMF fungi. Lineages are designated by a ' $/$ ' (slash) 
followed by the dominant genus, genera, or higher level taxon, for example, /cenococcum, /tomentella-thelephora and /atheliales 3 . We then computed richness, evenness and diversity (Shannon and Simpson indices) of EMF lineages according to McCune and Grace (2002). It is important to note that only roots with fungal infection were taken forward for DNA analysis; therefore, diversity indices analysed here do not take into account change in overall abundance of ECMs, only the fungi present on roots.

\section{Statistical Analyses}

Respiration data in 2013 and 2014 were analysed separately using a repeated measures two-way ANOVA following a linear mixed effects model with distance from tree and defoliation status (defoliated or non-defoliated) as categorical main effects. Data were square root transformed to meet the assumptions of the parametric analyses. A linear model was used to analyse the relationship between $\mathrm{NH}_{4}{ }^{+}$adsorbed to cation exchange membranes and the defoliation extent of the B. pubescens on the LS plots once the response variable was natural-log transformed. The relationship between defoliation extent and EMF ingrowth was analysed using a linear model. Once again, a natural-log transformation of the response variable made the data appropriate for parametric analysis. One outlying point was removed from the EMF ingrowth analysis because it had a disproportionate effect on the statistical model, violating the underlying assumptions (Cook's distance $>0.5$ ). A conservative Bonferroni test on its residual confirmed that this was indeed a statistical outlier $(P=0.0058)$ (Kutner and others 2005).

We compared richness, evenness and diversity (both Shannon's and Simpson's indices) of EMF lineages present on root tips between defoliated and non-defoliated trees with paired $t$ tests. To test a null hypothesis that EMF communities were not affected by defoliation, we used the non-parametric blocked multi-response permutation procedure in PC-ORD (McCune and Mefford 2011). The raw data matrix included counts of EMF fungal lineages and non-EMF fungi in defoliated and non-defoliated plots $(n=5)$. We considered plots as random blocks, performed within-block median averaging, and used distance function commensuration to give equal weighting to variables in the calculated Euclidian distance matrix (McCune and Grace 2002). EMF lineages were grouped into ET (Agerer 2001) based on their identification at lineage level. Differences in relative abundance of different ETs between defoliated and non-defoliated plots were analysed by Holm-Tukey multiple comparisons after a two-way ANOVA with defoliation status and ET as fixed effects.

\section{RESUlts}

There was a marginally significant $(P=0.058)$ positive linear relationship between the density of trees $(x)$ and extent of defoliation $(y)$ of each tree, as follows: $y=26.6+0.3 \times\left(R^{2}=12 \%\right)$.

Defoliated plots had a significantly lower soil respiration rate $\left(2.63 \mu \mathrm{mol} \quad \mathrm{CO}_{2} \mathrm{~m}^{-2} \mathrm{~s}^{-1}\right)$ than non-defoliated plots $\left(3.96 \mu \mathrm{mol} \mathrm{CO} \mathrm{CO}^{-2} \mathrm{~s}^{-1}\right)$ in 2013 when measured $50 \mathrm{~cm}$ from the tree $(P=0.015$; Table 1; Figure 2). However, the effect of defoliation overall was not significant $(P=0.068)$ due to a non-significant response to defoliation at $150 \mathrm{~cm}$ from the tree. Overall, there was a significant $(P=0.009)$ effect of distance on respiration rates and no significant interaction $(P=0.24)$ between distance and defoliation. The same pattern, with lower respiration at $50 \mathrm{~cm}$ from defoliated trees, continued into 2014.

There was a significant positive relationship between defoliation extent ( $\%$ defoliated) and the amount of $\mathrm{NH}_{4}{ }^{+}$sorbed to resin membranes during both sampling periods (July and September, 2013). The relationship was strongest in July $(P<0.001$, Figure 3A); however, it was still present in September $(P=0.004$, Figure $3 \mathrm{~B})$. There was also a significant negative relationship between defoliation extent and EMF hyphal production over the months of June-September $(P=0.005$, Figure 4). Nitrate was present in very low, almost undetectable, levels, and there was no significant relationship between amount of defoliation and $\log _{e}+1$ transformed, membrane-sorbed nitrate in either July $\left(P=0.76, R_{2}=0.04 \%\right)$ or September $\left(P=0.69, R_{2}=0.04 \%\right)$. Nitrate data are presented in Supplementary Information, Figures S1 and S2.

The EMF fungal communities present on root tips were significantly affected by defoliation. EMF fungal richness, evenness and diversity declined in association with defoliation (Table 2). Fungal community composition was altered, with some EMF taxa increasing and others decreasing with defoliation. The /cortinarius lineage was the most abundant EMF taxon of both non-defoliated and defoliated trees, representing $48-51 \%$ of relative EMF abundance (Figure 5), and its relative abundance was not affected by defoliation. In contrast, defoliation significantly affected the relative abundance of the /russula-lactarius lineage, which increased from $20 \%$ to $44 \%$ in non-defoliated and 
Table 1. Analysis of Variance of Defoliation, Distance from the Base of the Tree, and Their Interaction Effects on Soil Respiration

\begin{tabular}{|c|c|c|c|c|c|}
\hline Data & $y$ transformation & Factor & d.f. & $F$ & $P$ \\
\hline \multirow[t]{3}{*}{2013 Respiration } & \multirow[t]{3}{*}{ Square root } & Distance from tree & 1,8 & 11.68 & 0.009 \\
\hline & & Defoliation & 1,8 & 4.46 & 0.068 \\
\hline & & Distance*Defoliation & 1,8 & 1.62 & 0.24 \\
\hline \multirow[t]{3}{*}{2014 Respiration } & \multirow[t]{3}{*}{ Square root } & Distance from tree & 1,8 & 8.83 & 0.017 \\
\hline & & Defoliation & 1,8 & 3.25 & 0.11 \\
\hline & & Distance*Defoliation & 1,8 & 1.65 & 0.24 \\
\hline
\end{tabular}

Statistical results correspond to data shown in Figure 2
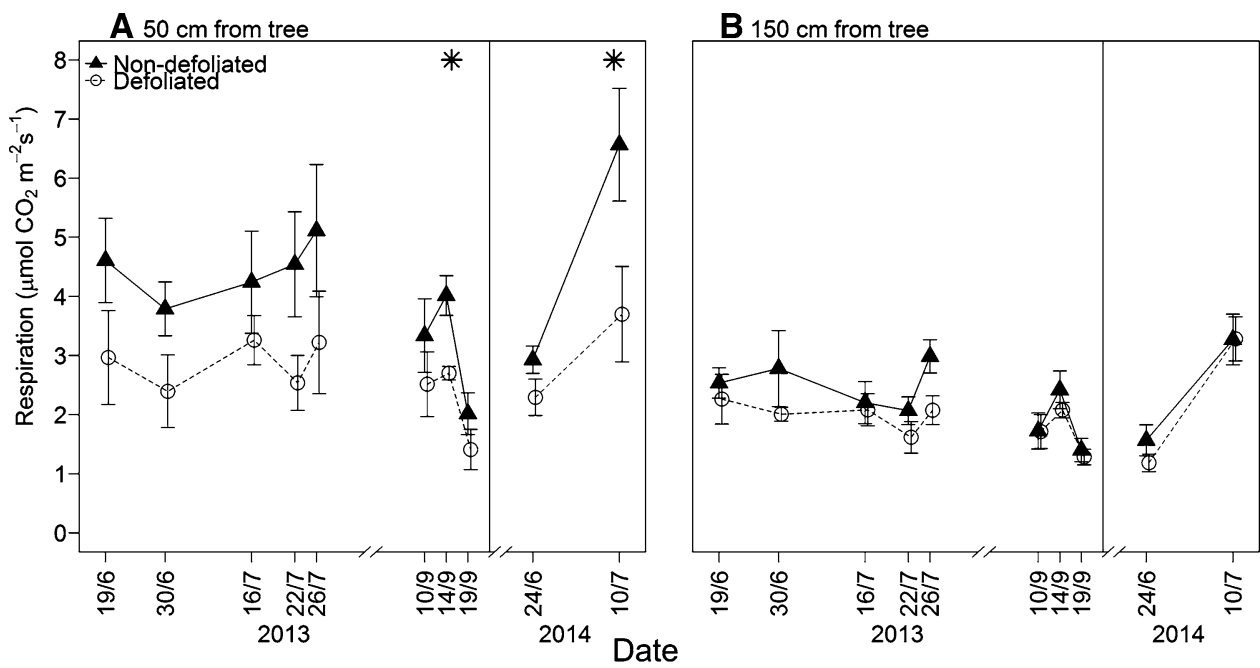

Figure 2. Soil respiration measured over the growing season of 2013 and 2014 at non-defoliated (closed triangles) and defoliated (open circles) plots at $\mathbf{A} 50 \mathrm{~cm}$ and $\mathbf{B} 150 \mathrm{~cm}$ from study trees. Error bars represent \pm one standard error of the mean $(n=5)$. * signifies a significant $(P<0.05)$ effect of defoliation within the statistical model in that year and distance from the tree, according to one degree of freedom Wald tests. Results of a factorial ANOVA test on the whole dataset are shown in Table 1.

defoliated trees, respectively. Additionally, the EMF lineages /tomentella-thelephora, /tomentellopsis, /piloderma, /cantharellus, /inocybe, /hydnellum-sarcodon, /amphinema-tylospora and /boletus, which together accounted for about $30 \%$ of EMF fungi of non-defoliated trees, collectively declined to $3 \%$ of the EMF community of defoliated trees. The lineages /hygrophorus, /meliniomyces and /cenococcum were present as EMF symbionts of roots obtained from single defoliated plots and were not detected in non-defoliated plots. Non-mycorrhizal fungi most closely related to root endophytes that included Phialocephala fortinii, $P$. sphaeroides and Meliniomyces variabilis, and freeliving litter decomposers (two Mycena spp.) were recovered mainly from EMF roots of defoliated trees (Table S1).
Amongst EMF lineages, those with high extraradical mycelium biomass (medium- and long-distance soil exploration strategy (Hobbie and Agerer 2010)) declined in relative abundance, from colonising $76 \%$ of EMF roots of non-defoliated trees to $43 \%$ of EMF roots of defoliated trees (Figure 5). This decline of high-biomass EMF ET with defoliation coincided with increased relative abundance of contact ET (consisting of /russulalactarius) and of non-mycorrhizal fungi (Figures 5 and 6).

\section{Discussion}

This study documents a series of changes in soil processes in response to defoliation that, taken together, suggest a slowdown of biogeochemical 


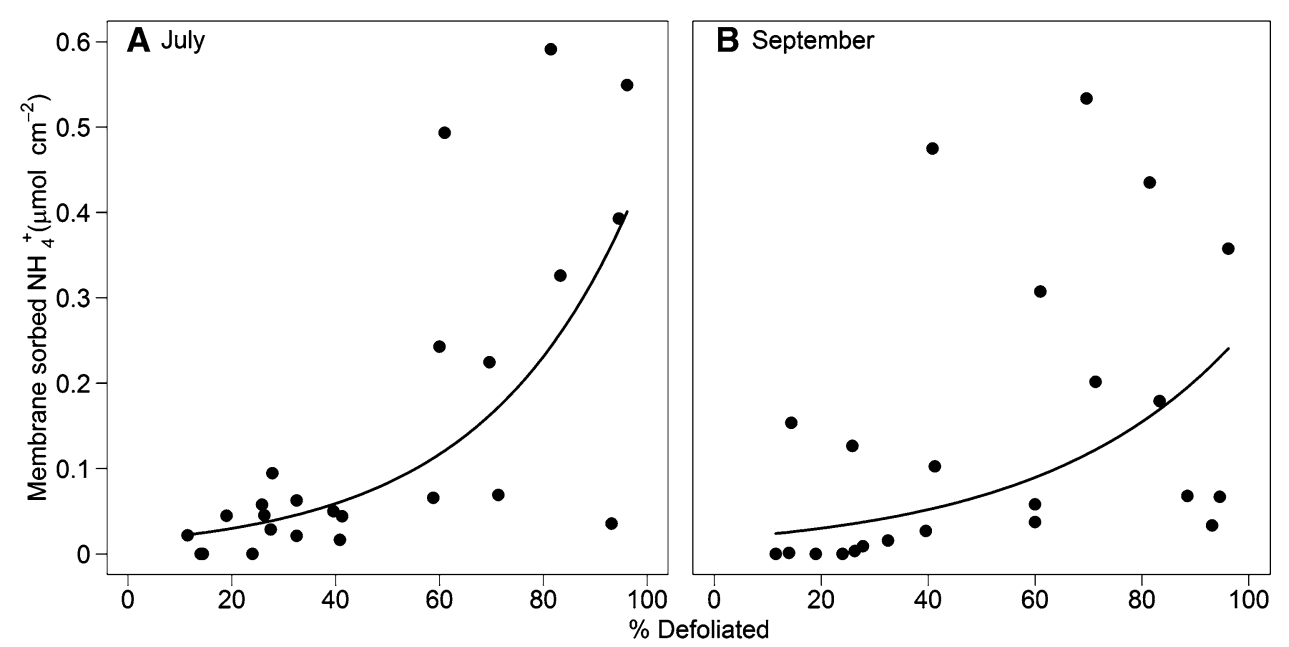

Figure 3. Resin membrane-sorbed ammonium ( $\mu$ mol $\mathrm{NH}_{4}{ }^{+} \mathrm{cm}^{-2}$ membrane) at $L S$ plots in $\mathbf{A}$ July and B September in relation to defoliation extent of B. pubescens ( $\%$ defoliated). July: $y=e^{0.034 x-4.19}, R^{2}=0.56$. Non-linear regression: d.f. $=1,22, t=5.49, \quad P<0.001$. September: $y=e^{0.027 x-4.05} R^{2}=0.31$. Non-linear regression: $d . f .=1,21, t=2.43$, $P=0.0036)$.

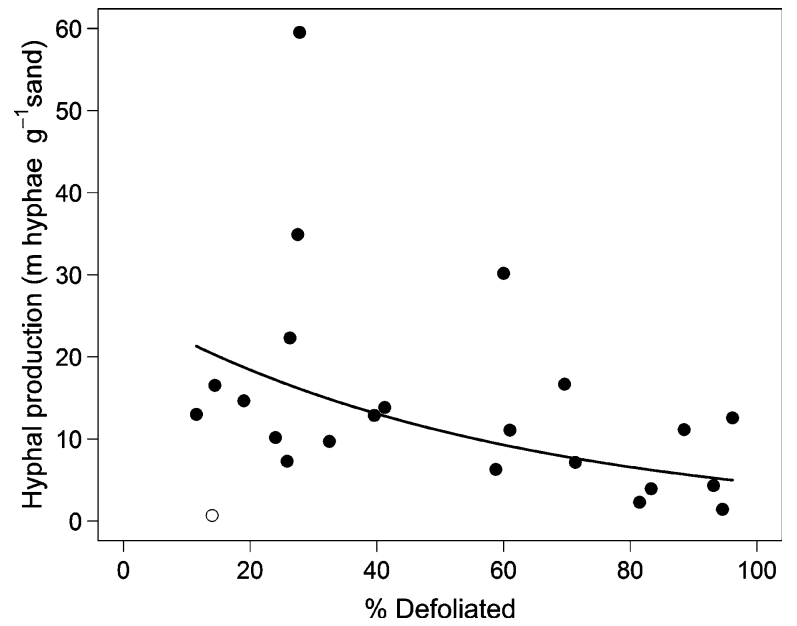

Figure 4. Hyphal ingrowth in relation to defoliation of B. pubescens (\% defoliated) at the LS plots. Line represents $y=e^{-0.017 x+3.26}, R^{2}=0.30$, without statistical outlier. Non-linear regression: d.f. $=1,20, t=3.17, \quad P=0.0048$. Statistical outlier is identified as an open circle; no other points were statistical outliers.

cycling. The data suggest that a reduction in ectomycorrhizal (EMF) production and a shift in EMF community composition could be important contributory factors involved in the slowdown of $\mathrm{C}$ and $\mathrm{N}$ cycling in the soil.

Previous work in this system has shown that large defoliation events drastically reduce the strength of the ecosystem C sink (Heliasz and others 2011). Here we demonstrate that the reduction in $\mathrm{C}$ assimilation also slows the loss of $\mathrm{C}$ from the soil (as respiration). This was only statistically significant, however, closer to the tree base (at 50 $\mathrm{cm})$, presumably where the tree has a greater influence on soil carbon cycling rates. These data suggest that the belowground respiration rate is sensitive to a reduction in aboveground $\mathrm{C}$ assimilation, as observed in experimental girdling and trenching experiments (Högberg and others 2001; Brzostek and others 2015). The effect of the defoliation on $\mathrm{C}$ cycling across the rest of the forest $(\geq 150 \mathrm{~cm}$ from tree base) may be negligible, as we observed no reduction in respiration further away from study trees. There will therefore be large areas of forest soil where soil $\mathrm{CO}_{2}$ efflux may not be directly affected by the defoliation of the canopy, although subtler (undetected here) effects cannot be ruled-out, and could relate, for example, to changes in soil thermal and/or moisture regimes in response to defoliation.

This study in forest plots which have undergone almost complete defoliation in a relatively unproductive ecosystem (Myneni and others 2001; Karlsen and others 2008) shows the opposite response to more productive ecosystems, which experienced a smaller reduction in belowground $\mathrm{C}$ allocation. In a temperate deciduous system, belowground respiration rates increased in response to relatively mild defoliation $(8 \%$ less foliage than control; (Frost and Hunter 2004)). This was similar to patterns of increased $\mathrm{C}$ allocation belowground by plants in response to partial 
Table 2. Effect of Defoliation on Ectomycorrhizal Fungal Community Richness $(S)$, Evenness $(E)$, Shannon Diversity $\left(H^{\prime}\right)$, Simpson Diversity $\left(D^{\prime}\right)$ and Composition

\begin{tabular}{llllll}
\hline & $S$ & $E$ & $H^{\prime}$ & $D^{\prime}$ & Composition \\
\hline Non-defoliated & $4.8 \pm 1.4$ & $0.83 \pm 0.07$ & $1.2 \pm 0.31$ & $0.60 \pm 0.12$ \\
Defoliated & $2.6 \pm 0.9$ & $0.43 \pm 0.19$ & $0.5 \pm 0.24$ & $0.28 \pm 0.13$ \\
$P>|t|$ & $0.04^{\mathrm{a}}$ & $0.05^{\mathrm{a}}$ & $0.04^{\mathrm{a}}$ & $0.05^{\mathrm{a}}$ & $0.04^{\mathrm{b}}$ \\
& & & & \\
$\begin{array}{l}\text { Values are means } \pm \text { standard error (n=5). } \\
\text { aaired t-test. } \\
{ }^{b} \text { Blocked multi-response permutation procedure t statistic. }\end{array}$ & & & \\
\hline
\end{tabular}

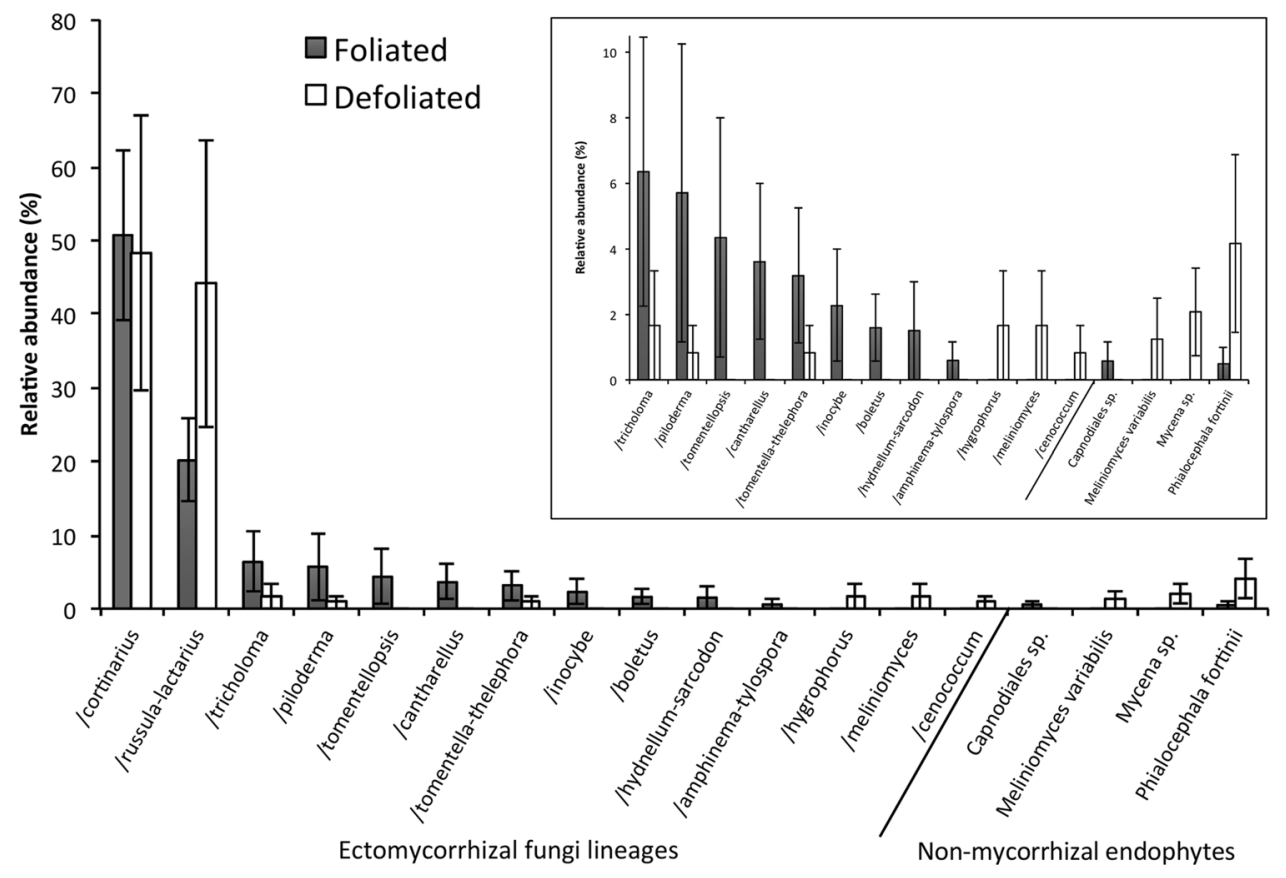

Figure 5. Main Relative abundance of ectomycorrhizal (EMF) fungal lineages and non-mycorrhizal (NM) fungi sequenced from ectomycorrhizal root tips of non-defoliated (grey bars) and defoliated (white bars) Betula. Error bars are standard error of the mean $(n=5)$ and undefined for unreplicated fungal lineages. Absence in replicates was treated as zero for mean relative abundance calculation. Relative abundance of non-ectomycorrhizal fungi is shown but excluded from analysis. Inset relative abundance of all but /cortinarius and /russula-lactarius lineages expressed on 0-12 scale.

herbivory (Bardgett and Wardle 2003; Orians and others 2011): Here the authors explained the increase in $\mathrm{C}$ flux as being due to a combination of increased root growth, turnover, activity and labile $\mathrm{C}$ input, all as mechanisms to recover $\mathrm{N}$ that was lost from leaf biomass (Frost and Hunter 2004). All of these processes depend on a high flux of autotrophic $\mathrm{C}$ to maintain roots and associated mycorrhizal symbionts (Litton and others 2007; Ekblad and others 2013; Brzostek and others 2015); something that was not possible in the present study as the defoliated trees suffered almost complete defoliation. In a subalpine forest suffering a bark beetle outbreak, as productivity decreased with tree death, ecosystem respiration decreased, signifying an overall slowdown of the forest $\mathrm{C}$ cycle (Moore and others 2013). This is analogous to the present study system; soil carbon cycling in subarctic forests relies on autotrophic C supply to stimulate the activity of microbial communities and continue the decomposition of soil organic matter (Hartley and others 2012). Our study demonstrates that when this $C$ supply is cut, cycling in the soil slows, further supporting the hypothesis that it is recently fixed carbon that drives this cycle (Hartley and others 2012). 


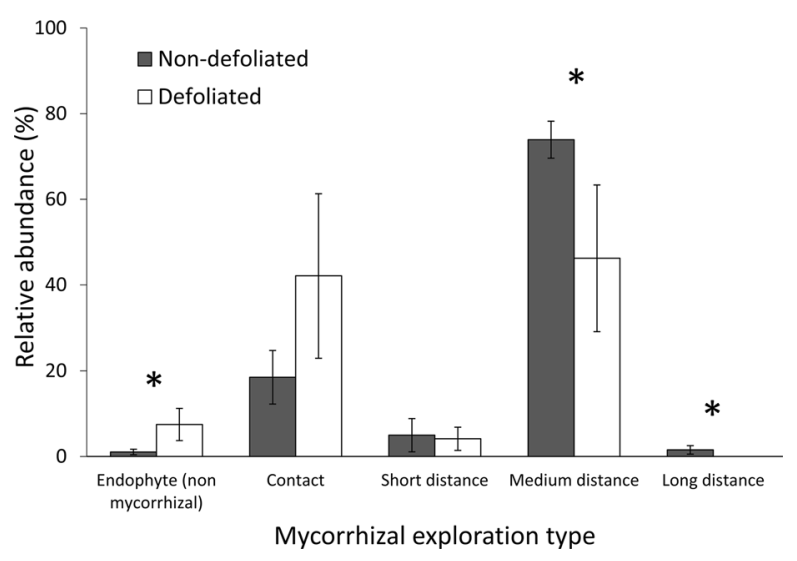

Figure 6. Effect of defoliation (non-defoliated in white defoliated in black), on relative abundance of non-mycorrhizal fungi and exploration types (ETs) of ectomycorrhizal fungi. Absence within replicates was counted as zero for mean relative abundance calculation. Bars are \pm one standard error of the mean. Asterisks indicate defoliation affected relative abundance of an ET (HolmTukey test) at $P<0.05$.

Free nitrogen $\left(\mathrm{NH}_{4}{ }^{+}\right)$in the soil was increased by an order of magnitude in extreme cases of defoliation compared to relatively unaffected areas of forest. Furthermore, free $\mathrm{NH}_{4}{ }^{+}-\mathrm{N}$ in the soil increased exponentially with defoliation extent, implying that accumulation of $\mathrm{N}$ in the soil results from multiple processes as opposed to simply being a linear function of frass input or any other single factor. It is therefore clear that the $\mathrm{N}$ cycle in this system was drastically altered by defoliation. One important likely change in $\mathrm{N}$ flux with defoliation was a reduction in root uptake (Kosola and others 2001). Additionally, although not measured directly, it is reasonable to assume that insect frass input scaled linearly with the severity of defoliation in the forest (Lovett and Ruesink 1995; Lovett and others 2002). Therefore, the large amount of free $\mathrm{N}$ observed in the soil was probably a product of increased direct $\mathrm{N}$ input via frass, as well as on-going mineralisation (Sjögersten and Wookey 2005), which was not balanced by an increase in uptake by roots and microbial biomass (Lovett and Ruesink 1995). In fact, root growth and uptake of $\mathrm{N}$ were likely dramatically reduced in the severely defoliated plots (Kosola and others 2001; Cigan and others 2015; Saravesi and others 2015). In this case, the argument for reduced root activity due to reductions in autotrophic $\mathrm{C}$ supply is also supported by the observed reduction in soil respiration rates, similar to what is observed when trees are girdled (Högberg and others 2001). In contrast to $\mathrm{NH}_{4}{ }^{+}-\mathrm{N}$, exchangeable $\mathrm{NO}_{3}{ }^{-}-\mathrm{N}$ was present at very low levels and was not related to the extent of defoliation of the forest canopy (Figures S1 and S2). Although not addressing defoliation effects, previous work by Sjögersten and Wookey (2005) identified a similar predominance $(\sim 2$ orders of magnitude) of $\mathrm{NH}_{4}{ }^{+}-\mathrm{N}$ over $\mathrm{NO}_{3}{ }^{-}-\mathrm{N}$ in a nearby mountain birch forest. Furthermore, isotope tracing studies have also shown that available $\mathrm{NO}_{3}{ }^{-}-\mathrm{N}$ is significantly lower than $\mathrm{NH}_{4}{ }^{+}-\mathrm{N}$ in the soil, and is relatively unresponsive to defoliation events (Christenson and others 2002).

Work at a different defoliated sub-arctic birch forest in Finland also showed that free $\mathrm{N}$ availability increased in defoliated plots, with the authors of this study suggesting that defoliation shifts the decomposer community to one in which bacteria become more dominant, while the fungal decomposition pathway is weakened (Kaukonen and others 2013). Therefore we speculate that $\mathrm{N}$ immobilisation by bacteria may have increased in the current study as their growth can be stimulated by the addition of free $\mathrm{N}$ when in combination with equally accessible $C$ inputs (Bååth and others 1978), as is the case with defoliation events (Lovett and Ruesink 1995).

We documented a decline in EMF hyphal production with increasing defoliation which was likely caused directly by a reduction in $\mathrm{C}$ supply from the defoliated host trees (Gehring and Whitham 1991; Gehring and others 1997; Kuikka and others 2003)). This decline in hyphal production was concomitant with a shift in the composition of the remaining EMF community. This has previously been observed in the soil after defoliation (Saravesi and others 2015) and in the present study, on root tips. Growth of EMF mycelium is known to be most directly influenced by the amount of carbon that is made available by autotrophic hosts (Ekblad and others 2013; Wallander and Ekblad 2015). Experimental reduction of this autotrophic $\mathrm{C}$ supply leads to loss of EMF biomass in the soil (Högberg and others 2001). Linked to C fluxes, EMF fungi are also an important sink for $\mathrm{N}$ in boreal forests (Mikusinska and others 2013; Näsholm and others 2013b) and can contain up to $200 \mathrm{~kg} \mathrm{~N} \mathrm{ha}^{-1}$ in their biomass (Wallander and others 2004). It has been suggested that EMF fungi immobilise more $\mathrm{N}$, and transfer less to trees, in low $\mathrm{N}$ environments in order to maintain their host's reliance on them (Näsholm and others 2013b). Therefore, a reduction in EMF hyphal production, as was observed here, may have contributed to the flush of inorganic $\mathrm{N}$ as the EMF failed to immobilise the excess $\mathrm{N}$ from the larval frass input (Lovett and Ruesink 1995). 
The shift in community composition of the remaining EMF root tips in defoliated plots may also have had a significant role in the reduced immobilisation of $\mathrm{N}$. There was a shift in the EMF fungi colonising B. pubescens roots from medium and long-distance ET in non-defoliated plots to smooth-mantled contact lineages such as /russulalactarius in the defoliated plots (Agerer and others 2012). This is consistent with the hypothesis that when a host tree is defoliated, EMF species with a lower $\mathrm{C}$ requirement hold a competitive advantage over those that invest in more extensive soil exploration (Saikkonen and others 1999; Markkola and others 2004). A similar shift to increased dominance of the /russula-lactarius lineage on EMF root tips and a reduction of mycelial biomass on EMF roots was observed in another mountain birch forest in response to defoliation (Saravesi and others 2015). The opposite occurred in a warming experiment on the Alaskan tundra where the biomass of $B$. nana increased; there, a shift to the more explorative Cortinarius spp. from the lower plant $C$ investment Russula spp., was observed, presumably as a result of increased plant $\mathrm{C}$ supplied belowground (Deslippe and others 2011). In this study, Cortinarius spp. remained unchanged in relative abundance, which could be of ecological significance; Cortinarius spp. are thought to be of particular importance to $\mathrm{N}$ cycling in arctic and boreal ecosystems because they use oxidative enzymes to extract $\mathrm{N}$ from complex organic molecules (Bödeker and others 2014) and could be important species in the transfer of $\mathrm{N}$ to host plants (Deslippe and others 2015). Species of Cortinarius have been shown to reduce expression of genes related to oxidative enzyme production under $\mathrm{N}$ fertilisation (Bödeker and others 2014). Here, where direct uptake of excess $\mathrm{N}$ under defoliated conditions would seem more favourable, Cortinarius spp. may have also reduced use of enzymes, which may slow decomposition of soil organic carbon. In our study, the shift in the composition of the EMF community likely contributed to the reduction of EMF hyphal production that was observed in highly defoliated plots and may also have indirectly contributed towards high concentrations of free $\mathrm{NH}_{4}{ }^{+}-\mathrm{N}$ in the soil.

An intriguing change in fungal community composition on root tips observed here was a clear increase in non-mycorrhizal endophytes. Although these fungi are common across the world, especially in stressful environments, their ecological function is largely unknown (Rodriguez and others 2009). One suggestion is that they become preferred as a low $\mathrm{C}$ cost symbiont when a plant is under stress in order to protect roots from pathogens (Mandyam and Jumpponen 2005), which is a reasonable explanation in this case. Alternatively, evidence has suggested that root endophytes can increase on roots in response to defoliation and that this may be in order to take advantage of root dieback (Saravesi and others 2014). Further work addressing why root endophytes increase beneath defoliated forests is clearly an interesting avenue of research and may shed further light on this poorly understood group of fungi.

Moth outbreaks in this area are known to be limited by minimum winter temperature, with a temperature lower than around $-35{ }^{\circ} \mathrm{C}$ known to freeze and kill over-wintering eggs (Tenow and Nilssen 1990). Increases in temperature and concurrent reductions in the number of days below- $-35^{\circ} \mathrm{C}$ have been shown to increase the range of both E. autumnata and O. brumata (Jepsen and others 2008). The latter has undergone particularly large increases in its range as it is more sensitive to cold temperatures than E. autumnata. In this study, there was an observed, although weak relationship between the density of trees and severity of defoliation. This was likely due to conditions that determine insect survival over winter through the differential probability of lethal super-cooling of eggs (Tenow and Nilssen 1990). At a larger scale, lethal winter air temperatures can be influenced by topography (Tenow and Nilssen 1990). At smaller scales, the availability of over-wintering sites can be the critical control of caterpillar survival and resulting defoliation (Bylund 1997). This was evident in old forests that had high outbreak numbers (many stems and over-wintering sites) and young forest with the opposite (Bylund 1997). Relationships such as these may be useful, in combination with ecosystem studies such as this and others (Heliasz and others 2011; Kaukonen and others 2013; Saravesi and others 2015), to derive a better understanding of the larger scale influence of Winter and Autumn Moths on whole ecosystem processes.

Herbivorous insect distributions and populations are known to be particularly responsive to winter and summer temperature increases (Bale and others 2002) and with this in mind, along with the observed past changes in moth ranges in relation to warming (Jepsen and others 2008), it appears likely that this kind of disturbance will increase in severity and magnitude in the coming century (Bale and others 2002) and may also have the potential to modulate forest expansion.

In summary, a large-scale defoliation event by $O$. brumata and E. autumnata caused a number of 
cascading effects in sub-arctic mountain birch forests. A reduced delivery of autotrophic $\mathrm{C}$ to the rhizosphere may have contributed towards accumulation of mineral $\mathrm{N}$ in the soil, which may have been linked in part to the altered composition and growth of the EMF community. In defoliation events, the accumulation of free $\mathrm{N}$ in the soil is initiated by frass inputs (Lovett and others 2002), but this phenomenon may persist in this study ecosystem because the influence of trees in the soil is diminished to the point where they can no longer drive immobilisation, either by direct uptake (Russell and others 2004) or through EMF fungi (Näsholm and others 2013b). We argue that the defoliated mountain birch forest resembles an Nsaturated ecosystem (Aber 1992) where biological immobilisation of $\mathrm{N}$ cannot keep pace with inputs due to a reduction in 'top-down' control. A research priority remains to measure further the longevity of response observed here in order to understand better the stoichiometry of $\mathrm{C}$ and $\mathrm{N}$ in the wake of these important disturbances. The EMF community is known to be a key link between changes in autotrophic $\mathrm{C}$ supply and cycling of $\mathrm{C}$ and $\mathrm{N}$ in the soil. Defoliation events are a feature of many forest ecosystems (particularly in sub-arctic, boreal and temperate regions), yet we still know little of the complex processes and cascading interactions that they drive. In an era of rapid environmental changes, where short-lived and mobile insect species are able to respond rapidly to new opportunities for range expansion, the severity of 'outbreak' years will likely have more profound ecosystem impacts. Further work needs to focus on the interactions and potentially non-linear effects of defoliation events to understand better how these important ecological events exert control over ecosystem processes and the $\mathrm{C}$ budget of these forests.

\section{ACKNOWLEDGEMENTS}

This work was supported by NERC (UK Natural Environment Research Council) research Studentship training grant NE/J500434/1. The research leading to these results has also received funding from the European Union Seventh Framework Programme [FP7/2007-2013] under grant agreement $\mathrm{n}^{\circ} 262693$ [INTERACT]. We would like to thank staff at Abisko Scientific Research Station warmly for hosting us and for supporting this work, and members of the Climate Impacts Research Centre for the loan of essential equipment. Thanks to Duncan Cameron and Gareth Phoenix for support at the University of Shef- field. Thanks also to Christina Fraser for help setting the plots up and to David Johnson (University of Sheffield) for lab assistance. The mycorrhizal community composition component of this research was supported by the Northern Ecosystems Research for Undergraduates Program funded by the US National Science Foundation (EAR 1063037). We thank Elizabeth Golden for assistance with sample collection and analysis.

\section{OPEN ACCESS}

This article is distributed under the terms of the Creative Commons Attribution 4.0 International License (http://creativecommons.org/licenses/by/ 4.0/), which permits unrestricted use, distribution, and reproduction in any medium, provided you give appropriate credit to the original author(s) and the source, provide a link to the Creative Commons license, and indicate if changes were made.

\section{REFERENCES}

Aber JD. 1992. Nitrogen cycling and nitrogen saturation in temperate forest ecosystems. Trends Ecol Evol 7:220-4.

Agerer R, Hartmann A, Pritsch K, Raidl S, Schloter M, Verma R, Weigt R. 2012. Plants and their ectomycorrhizosphere: cost and benefit of symbiotic soil organisms. Growth Def Plants $220: 213-42$.

Agerer R. 2001. Exploration types of ectomycorrhizae-a proposal to classify ectomycorrhizal mycelial systems according to their patterns of differentiation and putative ecological importance. Mycorrhiza 11:107-14.

Avis PG, McLaughlin DJ, Dentinger BC, Reich PB. 2003. Longterm increase in nitrogen supply alters above- and belowground ectomycorrhizal communities and increases the dominance of Russula spp. in a temperate oak savanna. New Phytol 160:239-53.

Bååth E, Lohm U, Lundgren B. 1978. The effect of nitrogen and carbon supply on the development of soil organism populations and pine seedlings: a microcosm experiment. Oikos 31:153-63. http://www.jstor.org/stable/3543558. Last accessed 03/01/2016.

Bale JS, Masters GJ, Hodkinson ID, Awmack C, Bezemer TM, Brown VK, Butterfield J, Buse A, Coulson JC, Farrar J, Good JEG, Harrington R, Hartley S, Jones TH, Lindroth RL, Press MC, Symrnioudis I, Watt AD, Whittaker JB. 2002. Herbivory in global climate change research: direct effects of rising temperature on insect herbivores. Global Change Biol 8:1-16.

Bardgett RD, Wardle DA. 2003. Herbivore-mediated linkages between aboveground and belowground communities. Ecology 84:2258-68.

Bjerke JW, Karlsen SR, Hogda KA, Malnes E, Jepsen JU, Lovibond S, Vikhamar-Schuler D, Tommervik H. 2014. Recordlow primary productivity and high plant damage in the Nordic Arctic Region in 2012 caused by multiple weather events and pest outbreaks. Environ Res Lett 9:084006.

Blume-Werry G, Wilson SD, Kreyling J, Milbau A. 2016. The hidden season: growing season is $50 \%$ longer below than above ground along an arctic elevation gradient. New Phytol 209:978- 
86. http://www.ncbi.nlm.nih.gov/pubmed/26390239. Last accessed 18/03/2016.

Bödeker ITM, Clemmensen KE, de Boer W, Martin F, Olson A, Lindahl BD. 2014. Ectomycorrhizal Cortinarius species participate in enzymatic oxidation of humus in northern forest ecosystems. New Phytol 203:245-56. doi:10.1111/nph.12791.

Van Bogaert R, Haneca K, Hoogesteger J, Jonasson C, De Dapper M, Callaghan TV. 2011. A century of tree line changes in subArctic Sweden shows local and regional variability and only a minor influence of 20th century climate warming. J Biogeogr 38:907-21.

Brundrett M, Melville L, Peterson L. 1994. Practical methods in mycrorrhiza research. Waterloo: Mycologue Publications.

Brzostek ER, Dragoni D, Brown ZA, Phillips RP. 2015. Mycorrhizal type determines the magnitude and direction of rootinduced changes in decomposition in a temperate forest. New Phytol 306:1274-82. doi:10.1111/nph.13303.

Bylund H. 1997. Stand age-structure influence in a low population peak of Epirrita autumnata in a mountain birch forest. Ecography 20:319-26.

Christenson LM, Lovett GM, Mitchell MJ, Groffman PM. 2002. The fate of nitrogen in gypsy moth frass deposited to an Oak forest floor. Oecologia 131:444-52.

Cigan PW, Karst J, Cahill JF, Sywenky AN, Pec GJ, Erbilgin N. 2015. Influence of bark beetle outbreaks on nutrient cycling in native pine stands in western Canada. Plant Soil . doi:10. 1007/s11104-014-2378-0.

DeLuca TH, Zackrisson O, Nilsson MC, Sellstedt A. 2002. Quantifying nitrogen-fixation in feather moss carpets of boreal forests. Nature 419:917-20.

Deslippe JR, Hartmann M, Grayston SJ, Simard SW, Mohn WW. 2015. Stable isotope probing implicates a species of Cortinarius in carbon transfer through ectomycorrhizal fungal mycelial networks in Arctic tundra. New Phytol. http://www.ncbi. nlm.nih.gov/pubmed/26681156. Last accessed 22/12/2015.

Deslippe JR, Hartmann M, Mohn WW, Simard SW. 2011. Longterm experimental manipulation of climate alters the ectomycorrhizal community of Betula nana in Arctic tundra. Global Change Biol 17:1625-36.

Ekblad A, Wallander H, Godbold DL, Cruz C, Johnson D, Baldrian P, Bjork RG, Epron D, Kieliszewska-Rokicka B, Kjoller R, Kraigher H, Matzner E, Neumann J, Plassard C. 2013. The production and turnover of extramatrical mycelium of ectomycorrhizal fungi in forest soils: role in carbon cycling. Plant Soil 366:1-27.

Frost CJ, Hunter MD. 2004. Insect canopy herbivory and frass deposition affect soil nutrient dynamics and export in oak mesocosms. Ecology 85:3335-47.

Frost CJ, Hunter MD. 2007. Recycling of nitrogen in herbivore feces: plant recovery, herbivore assimilation, soil retention, and leaching losses. Oecologia 151:42-53.

Gardes M, Bruns TD. 1993. Its primers with enhanced specificity for basidiomycetes-application to the identification of mycorrhizae and rusts. Mol Ecol 2:113-18.

Gehring CA, Cobb NS, Whitman TG. 1997. Three-way interactions among ectomycorrhizal mutualists, scale insects, and resistant and susceptible pinyon pines. Am Nat 149:824-41.

Gehring CA, Whitham TG. 1991. Herbivore-driven mycorrhizal mutualism in insect-susceptible pinyon pine. Nature 353:556-

Hartley IP, Garnett MH, Sommerkorn M, Hopkins DW, Fletcher BJ, Sloan VL, Phoenix GK, Wookey PA. 2012. A potential loss of carbon associated with greater plant growth in the European Arctic. Nat Clim Change 2:875-9.

Hartley IP, Hopkins DW, Sommerkorn M, Wookey PA. 2010. The response of organic matter mineralisation to nutrient and substrate additions in sub-arctic soils. Soil Biol Biochem 42:92-100.

Heliasz M, Johansson T, Lindroth A, Molder M, Mastepanov M, Friborg T, Callaghan TV, Christensen TR. 2011. Quantification of $\mathrm{C}$ uptake in subarctic birch forest after setback by an extreme insect outbreak. Geophys Res Lett 38:5.

Hicke JA, Allen CD, Desai AR, Dietze MC, Hall RJ, Hogg EH, Kashian DM, Moore D, Raffa KF, Sturrock RN, Vogelmann J. 2012. Effects of biotic disturbances on forest carbon cycling in the United States and Canada. Global Change Biol 18:7-34.

Hobbie EA, Agerer R. 2010. Nitrogen isotopes in ectomycorrhizal sporocarps correspond to belowground exploration types. Plant Soil 327:71-83.

Hobbie EA. 2006. Carbon allocation to ectomycorrhizal fungi correlates with belowground allocation in culture studies. Ecology 87:563-9.

Hofgaard A, Tommervik H, Rees G, Hanssen F. 2013. Latitudinal forest advance in northernmost Norway since the early 20th century. J Biogeogr 40:938-49.

Högberg P, Nordgren A, Buchmann N, Taylor AFS, Ekblad A, Högberg MN, Nyberg G, Ottosson-Lofvenius M, Read DJ. 2001. Large-scale forest girdling shows that current photosynthesis drives soil respiration. Nature 411:789-92.

Jepsen JU, Biuw M, Ims RA, Kapari L, Schott T, Vindstad OPL, Hagen SB. 2013. Ecosystem impacts of a range expanding forest defoliator at the forest-tundra ecotone. Ecosystems 16:561-75.

Jepsen JU, Hagen SB, Ims RA, Yoccoz NG. 2008. Climate change and outbreaks of the geometrids Operophtera brumata and Epirrita autumnata in subarctic birch forest: evidence of a recent outbreak range expansion. J Anim Ecol 77:257-64.

Jepsen JU, Kapari L, Hagen SB, Schott T, Vindstad OPL, Nilssen AC, Ims RA. 2011. Rapid northwards expansion of a forest insect pest attributed to spring phenology matching with subArctic birch. Global Change Biol 17:2071-83.

Kaiser C, Fuchslueger L, Koranda M, Gorfer M, Stange CF, Kitzler B, Rasche F, Strauss J, Sessitsch A, Zechmeister-Boltenstern S, Richter A. 2011. Plants control the seasonal dynamics of microbial $\mathrm{N}$ cycling in a beech forest soil by belowground C allocation. Ecology 92:1036-51.

Karlsen SR, Tolvanen A, Kubin E, Poikolainen J, Hogda KA, Johansen B, Danks FS, Aspholm P, Wielgolaski FE, Makarova O. 2008. MODIS-NDVI-based mapping of the length of the growing season in northern Fennoscandia. Int J Appl Earth Obs Geoinf 10:253-66.

Kaukonen M, Routsalainen AL, Wäli PR, Männistö MK, Setälä H, Saravesi K, Huusko K, Markkola A. 2013. Moth herbivory enhances resource turnover in subarctic mountain birch forests? Ecology 94:267-72.

Kennedy PG, Hill LT. 2010. A molecular and phylogenetic analysis of the structure and specificity of Alnus rubra ectomycorrhizal assemblages. Fungal Ecol 3:195-204.

Kosola KR, Dickmann DI, Paul EA, Parry D. 2001. Repeated insect defoliation effects on growth, nitrogen acquisition, carbohydrates, and root demography of poplars. Oecologia 129:65-74.

Kuikka K, Harma E, Markkola A, Rautio P, Roitto M, Saikkonen K, Ahonen-Jonnarth U, Finlay R, Tuomi J. 2003. Severe 
defoliation of scots pine reduces reproductive investment by ectomycorrhizal symbionts. Ecology 84:2051-61.

Kutner MH, Nachtsheim CJ, Neter J, Li W. 2005. Applied linear statistical models. 5th edn. New York: McGraw-Hill/Irwin.

Lindahl BD, de Boer W, Finlay RD. 2010. Disruption of root carbon transport into forest humus stimulates fungal opportunists at the expense of mycorrhizal fungi. ISME J 4:872-81.

Lindahl BD, Ihrmark K, Boberg J, Trumbore SE, Högberg P, Stenlid J, Finlay RD. 2007. Spatial separation of litter decomposition and mycorrhizal nitrogen uptake in a boreal forest. New Phytol 173:611-20.

Litton CM, Raich JW, Ryan MG. 2007. Carbon allocation in forest ecosystems. Global Change Biol 13:2089-109.

Lovett GM, Christenson LM, Groffman PM, Jones CG, Hart JE, Mitchell MJ. 2002. Insect defoliation and nitrogen cycling in forests. Bioscience 52:335-41.

Lovett GM, Ruesink AE. 1995. Carbon and nitrogen mineralization from decomposing gypsy-moth frass. Oecologia 104:133-8.

Mandyam K, Jumpponen A. 2005. Seeking the elusive function of the root-colonising dark septate endophytic fungi. Stud Mycol 53:173-89. http://www.sciencedirect.com/science/ article/pii/S0166061614602293. Last accessed 01/04/2016.

Markkola A, Kuikka K, Rautio P, Harma E, Roitto M, Tuomi J. 2004. Defoliation increases carbon limitations in ectomycorrhizal symbiosis of Betula pubescens. Oecologia 140:234-40.

McCune B, Grace JB. 2002. Analysis of ecological communities. Gleneden Beach: MjM Software.

McCune B, Mefford MJ. 2011. PC-ORD. Multivariate analysis of ecological data. Version 6. Gleneden Beach: MjM Software.

Mikusinska A, Persson T, Taylor AFS, Ekblad A. 2013. Response of ectomycorrhizal extramatrical mycelium production and isotopic composition to in-growth bag size and soil fauna. Soil Biol Biochem 66:154-62. http://www.sciencedirect.com/ science/article/pii/S0038071713002563. Last accessed 30/11/ 2015.

Moore DJP, Trahan NA, Wilkes P, Quaife T, Stephens BB, Elder K, Desai AR, Negron J, Monson RK. 2013. Persistent reduced ecosystem respiration after insect disturbance in high elevation forests. Ecol Lett 16:731-7.

Myneni RB, Dong J, Tucker CJ, Kaufmann RK, Kauppi PE, Liski J, Zhou L, Alexeyev V, Hughes MK. 2001. A large carbon sink in the woody biomass of Northern forests. Proc Natl Acad Sci USA 98:14784-9.

Näsholm T, Högberg P, Franklin O, Metcalfe D, Keel SG, Campbell C, Hurry V, Linder S, Högberg MN. 2013a. Are ectomycorrhizal fungi alleviating or aggravating nitrogen limitation of tree growth in boreal forests? New Phytol 198:214-21.

Näsholm T, Högberg $P$, Franklin $O$, Metcalfe D, Keel SG, Campbell C, Hurry V, Linder S, Högberg MN. 2013b. Are ectomycorrhizal fungi alleviating or aggravating nitrogen limitation of tree growth in boreal forests? New Phytol 198:214-21. http://www.ncbi.nlm.nih.gov/pubmed/233565 03. Last accessed 09/10/2015.

Orians CM, Thorn A, Gomez S. 2011 . Herbivore-induced resource sequestration in plants: why bother? Oecologia 167:1-9.

Parker TC, Subke J-A, Wookey PA. 2015. Rapid carbon turnover beneath shrub and tree vegetation is associated with low soil carbon stocks at a subarctic treeline. Global Change Biol
21:2070-81. http://www.ncbi.nlm.nih.gov/pubmed/253670 88. Last accessed 22/04/2015.

Qian P, Schoenau JJ. 2002. Practical applications of ion exchange resins in agricultural and environmental soil research. Can J Soil Sci 82:9-21.

Quirk J, Beerling DJ, Banwart SA, Kakonyi G, Romero-Gonzalez ME, Leake JR. 2012. Evolution of trees and mycorrhizal fungi intensifies silicate mineral weathering. Biol Lett 8:1006-11.

Rodriguez RJ, White JF, Arnold AE, Redman RS. 2009. Fungal endophytes: diversity and functional roles. New Phytol 182:314-30. http://www.ncbi.nlm.nih.gov/pubmed/192365 79. Last accessed 01/05/2016.

Rundqvist S, Hedenas H, Sandstrom A, Emanuelsson U, Eriksson H, Jonasson C, Callaghan TV. 2011. Tree and shrub expansion over the past 34 years at the tree-line near Abisko, Sweden. Ambio 40:683-92.

Russell CA, Kosola KR, Paul EA, Robertson GP. 2004. Nitrogen cycling in poplar stands defoliated by insects. Biogeochemistry 68:365-81.

Saikkonen K, Ahonen-Jonnarth U, Markkola AM, Helander M, Tuomi J, Roitto M, Ranta H. 1999. Defoliation and mycorrhizal symbiosis: a functional balance between carbon sources and below-ground sinks. Ecol Lett 2:19-26.

Saravesi K, Aikio S, Wäli PR, Ruotsalainen AL, Kaukonen M, Huusko K, Suokas M, Brown SP, Jumpponen A, Tuomi J, Markkola A. 2015. Moth outbreaks alter root-associated fungal communities in subarctic mountain Birch forests. Microb Ecol . doi:10.1007/s00248-015-0577-8.

Saravesi K, Ruotsalainen AL, Cahill JF. 2014. Contrasting impacts of defoliation on root colonization by arbuscular mycorrhizal and dark septate endophytic fungi of Medicago sativa. Mycorrhiza 24:239-45. http://www.ncbi.nlm.nih.gov/pub med/24197419. Last accessed 01/05/2016.

Sjögersten S, Wookey PA. 2002. Climatic and resource quality controls on soil respiration across a forest-tundra ecotone in Swedish Lapland. Soil Biol Biochem 34:1633-46.

Sjögersten S, Wookey PA. 2005. The role of soil organic matter quality and physical environment for nitrogen mineralization at the forest-tundra ecotone in Fennoscandia. Arct Antarct Alp Res 37:118-26.

Sloan VL, Fletcher BJ, Phoenix GK. 2015. Contrasting synchrony in root and leaf phenology across multiple sub-Arctic plant communities. J Ecol. doi: 10.1111/1365-2745.12506. Last accessed 09/11/2015.

Tedersoo L, Smith ME. 2013. Lineages of ectomycorrhizal fungi revisited: Foraging strategies and novel lineages revealed by sequences from belowground. Fungal Biol Rev 27:83-99.

Tenow O, Nilssen A. 1990. Egg cold hardiness and topoclimatic limitations to outbreaks of Epirrita autumnata in northern Fennoscandia. J Appl Ecol 27:723-34.

Tenow O, Nilssen AC, Bylund H, Hogstad O. 2007. Waves and synchrony in Epirrita autumnata/Operophtera brumata outbreaks. I. Lagged synchrony: regionally, locally and among species. J Anim Ecol 76:258-68.

Tømmervik H, Johansen B, Riseth JA, Karlsen SR, Solberg B, Hogda KA. 2009. Above ground biomass changes in the mountain birch forests and mountain heaths of Finnmarksvidda, northern Norway, in the period 1957-2006. For Ecol Manag 257:244-57.

Wallander H, Ekblad A, Godbold DL, Johnson D, Bahr A, Baldrian P, Bjork RG, Kieliszewska-Rokicka B, Kjoller R, Kraigher H, Plassard 
C, Rudawska M. 2013. Evaluation of methods to estimate production, biomass and turnover of ectomycorrhizal mycelium in forests soils—a review. Soil Biol Biochem 57:1034-47.

Wallander H, Ekblad A. 2015. The importance of ectomycorrhizal networks for nutrient retention and carbon sequestration in forest ecosystems. In: Horton TR, Ed. Mycorrhizal networks, Vol. 224Ecological studies, Netherlands: Springer. $p$ 69-90. doi:10.1007/978-94-017-7395-9_3

Wallander H, Göransson H, Rosengren U. 2004. Production, standing biomass and natural abundance of $15 \mathrm{~N}$ and $13 \mathrm{C}$ in ectomycorrhizal mycelia collected at different soil depths in two forest types. Oecologia 139:89-97. http://www.ncbi.nlm. nih.gov/pubmed/14727173. Last accessed 03/08/2015.

Wallander H, Nilsson LO, Hagerberg D, Bååth E. 2001. Estimation of the biomass and seasonal growth of external mycelium of ectomycorrhizal fungi in the field. New Phytol 151:753-60.

White TJ, Bruns TD, Lee SB, Taylor JW. 1990. Amplification and direct sequencing of fungal ribosomal RNA genes for phylogenetics. New York: Academic Press Inc. 